\title{
LATIHAN FISIK PADA FRAILTY SYNDROME
}

\author{
Joudy Gessal \\ Widya Utari \\ Rumah Sakit Umum Pusat Prof. Dr. R.D. Kandou Manado \\ Email: jgessal@yahoo.com
}

\begin{abstract}
Frailty Syndrome (FS) is a geriatric syndrome characterized by decreases of functional ability and adaptation due to multi-system functional degradation, and an increase of susceptibility to a variety of pressures, resulting in a decrease of functional performance and health status. FS occurs in $30 \%$ people over 80 years and in $7 \%$ over 65 years. The incidences of FS in females were higher than in males due to the females' smaller/lower/less body mass; therefore, loss of muscle mass due to aging process is faster. Anorexia, sarcopenia, immobilization, atherosclerosis, balance disorder, depression, and cognitive disorders are conditions that can lead to the occurences of FS. Although FS increases the morbidity and accelerates the mortality, the right type of exercise can overcome this syndrome and improves the quality of life.
\end{abstract}

Keywords: Frailty syndrome, geriatric, quality of life.

\begin{abstract}
Abstrak: Frailty Syndrome (FS) adalah suatu sindroma geriatrik dengan karakteristik berkurangnya kemampuan fungsional dan fungsi adaptasi yang diakibatkan oleh degradasi fungsi berbagai sistem dalam tubuh, serta meningkatnya kerentanan terhadap berbagai macam tekanan; kesemuanya ini menurunkan performa fungsional dan status kesehatan seseorang. Frailty Syndrome terjadi pada 30\% populasi di atas usia 80 tahun dan $7 \%$ pada populasi usia di atas 65 tahun. Insiden pada perempuan lebih tinggi oleh karena perempuan memiliki massa tubuh yang lebih kecil daripada laki-laki sehingga kehilangan massa otot lebih cepat terjadi pada proses aging. Anoreksia, sarkopenia, imobilisasi, aterosklerosis, gangguan keseimbangan, depresi dan gangguan kognitif merupakan kondisi-kondisi yang dapat menyebabkan terjadinya FS. Walaupun FS menyebabkan peningkatan morbiditas dan percepatan terjadinya mortalitas, latihan yang tepat dapat mengatasi sindroma dan meningkatkan kualitas hidup.
\end{abstract}

Kata kunci: frailty Syndrome, geriatrik, kualitas hidup.

Frailty Syndrome (FS) adalah suatu sindroma geriatri dengan karakteristik berkurangnya kemampuan fungsional dan gangguan fungsi adaptasi yang diakibatkan oleh merosotnya berbagai sistem tubuh, serta meningkatnya kerentanan terhadap berbagai macam tekanan, yang menurunkan performa fungsional seseorang. Masalah FS ini bersinggungan dengan proses penuaan (aging), disabilitas dan komorbiditas pada seseorang. Walaupun FS dan disabilitas saling berhubungan dan tumpang tindih, keduanya merupakan hal yang berbeda. ${ }^{1,2}$

Angka kejadian FS berkisar 7\% pada usia diatas 65 tahun dan $30 \%$ pada usia diatas 80 tahun. Pada penelitian terhadap ras Kaukasia, perempuan lebih banyak menderita FS dibandingkan laki-laki (7:5), sedangkan pada kelompok Afrika-Amerika didapatkan dua kali lipat dibandingkan ras Kaukasia (14:7). Secara patofisiologi, FS merupakan proses penurunan kemampuan multi-sistem akibat disregulasi oleh proses 
penuaan yang diawali dengan perubahan fisiologi karena usia, penyakit, kurangnya aktivitas, dan atau buruknya asupan nutrisi. $^{2-6}$

Sampai saat ini belum terdapat konsensus yang menetapkan definisi pasti dan kriteria diagnosis yang spesifik dari FS. Umumnya, untuk menentukan suatu FS dipergunakan kriteria klinis dari Fried et al. yaitu bila terdapat tiga atau lebih dari kriteria FS yang terdiri dari: kelemahan, berkurangnya kecepatan jalan, keluhan cepat lelah, menurunnya aktivitas, dan berkurangnya berat badan. ${ }^{2,3}$ Gambaran klinis FS sebelum munculnya efek buruk tampaknya bersumber dari kelemahan, berkurangnya kecepatan jalan, rasa cepat lelah, aktivitas fisik yang rendah, dan hilangnya berat badan. Diagnosis didasarkan atas tanda dan gejala klinis serta penyakit komorbidnya. ${ }^{2,4,8}$

Frailty syndrome merupakan prediktor untuk rawat inap, disabilitas, menurunnya mobilitas, jatuh, dan bahkan kematian. Mengobati sampai sembuh bukan hal yang mudah, karena setiap orang pasti menuju usia tua dan berpeluang mengalami gejala FS. Hal yang terbaik dilakukan ialah menerapkan langkah pencegahan untuk memperlambat munculnya dan progresivitas dari FS yang sudah terjadi serta dampaknya. Intervensi yang dapat diberikan yaitu obat-obatan, nutrisi, hormon, dan rehabilitasi berupa latihan fisik. Latihan fisik memberi banyak keuntungan, diantaranya meningkatkan mobilitas dalam aktivitas kehidupan sehari-hari (AKS), perbaikan pola berjalan, serta berkurangnya risiko cedera dan jatuh. Semua langkah pengobatan dan pencegahan tersebut merupakan upaya mengoptimalkan kesehatan dan meningkatkan kualitas hidup kaum lansia (lanjut usia), sehingga terbaring di rumah sakit bukan merupakan momok bagi lansia dan memberikan sebuah harapan untuk hidup lebih baik. ${ }^{2,4-10}$

\section{DEFINISI FRAILTY SYNDROME}

Frailty syndrome (FS) adalah suatu sindroma geriatrik dengan karakteristik berkurangnya kemampuan fungsional dan gangguan fungsi adaptasi yang diakibatkan oleh merosotnya berbagai sistem tubuh, serta meningkatnya kerentanan terhadap berbagai macam tekanan yang menurunkan performa fungsional seseorang. ${ }^{1,2}$

Rockwood et al. menyatakan bahwa FS adalah suatu sindroma multidimensi dari hilangnya cadangan (energi, kemampuan fisik, kesehatan) yang menyebabkan terjadinya kerentanan. Keadaan ini secara umum meningkat pada orang tua tetapi bukanlah merupakan hal yang tidak terhindarkan dari proses penuaan. Banyak lansia tidak mengalami FS dan tidak pernah mengalaminya tetapi keadaan ini dapat juga ditemukan pada orang muda. ${ }^{3,5}$

Frailty Syndrome berbeda dengan disabilitas; banyak pasien mengalami disabilitas tanpa disertai FS. Dalam penelitian Fried, sebanyak $72,8 \%$ lansia dengan FS tidak mengalami disabilitas dan $72 \%$ lansia dengan disabilitas tidak mengalami FS. Umumnya FS mengakibatkan suatu disabilitas dan biasanya mengindikasikan peningkatan resiko morbiditas dan mortalitas. Disabilitas tidak melibatkan berbagai sistem tubuh seperti pada FS dan hanya $28 \%$ orang dengan disabilitas (diukur dengan AKS dan skor penilaian AKS) yang mengalami FS. ${ }^{5,8,9}$

\section{SIKLUS FRAILTY SYNDROME}

Beberapa studi memasukkan nutrisi, inflamasi, dan anemia kedalam faktor risiko FS. Asupan yang rendah baik kalori maupun protein, vitamin $\mathrm{D}$, vitamin $\mathrm{E}$, vitamin $\mathrm{C}$, dan folat dapat juga menyebabkan terjadinya FS (Gambar 1). 1,5,11

Secara biologis FS berkembang secara perlahan tetapi progresif. Buchner dan Wagner menyarankan untuk mencegah perkembangan tersebut dengan cara menurunkan efek akibat faktor pencetus akut seperti infeksi atau cedera. Oleh karena itu, sangat penting untuk memaksimalkan pemulihan kekuatan dan fungsi setelah suatu penyakit akut. ${ }^{3,9}$

Penyakit yang dapat berkontribusi menyebabkan FS melalui jalur biologis 
langsung yaitu aterosklerosis dan inflamasi. Penyakit lain juga dapat berpotensi memicu dimulainya siklus FS dengan mempengaruhi komponen kunci seperti status gizi, muscle wasting, toleransi latihan, atau tingkat kegiatan (Gambar 1). Perubahan neuroendokrin juga merupakan faktor yang berpengaruh terhadap terjadinya FS. ${ }^{4,11,12}$

\section{PATOFISIOLOGI FRAILTY SYNDROMES}

Perkembangan bukti klinis menunjukkan bahwa FS ialah sindroma biologis yang ditandai oleh penurunan kemampuan multisistem yang disebabkan oleh disregulasi akibat penuaan. Awal FS ditandai dengan perubahan fisiologi karena usia, penyakit dan atau kurangnya aktivitas, atau buruknya asupan nutrisi. Perubahan tersebut bermanifestasi pada hilangnya massa otot tubuh, tulang, dan fungsi abnormal dari sistem imun, respons terhadap inflamasi dan sistem neuroendokrin juga respons tubuh dalam menjaga homeostasis. ${ }^{5-7,13}$

Terdapat hipotesis yang menyatakan disregulasi sistem tersebut tersembunyi dalam keadaan tanpa stres, dan akan menjadi nyata dalam keadaan stres seperti suhu tinggi, infeksi, atau kecelakaan. Hipotesis tersebut menjelaskan gambaran klinis pasien usia lanjut yang rapuh dan rentan terhadap stresor baik endogen maupun eksogen. Akibat kerentanan ini maka timbul masalah kesehatan dengan gambaran klinis yang berhubungan dengan FS. Tingginya FS pada perempuan dikarenakan perempuan memiliki massa tubuh yang lebih kecil sehingga kehilangan massa otot dengan bertambahnya usia akan mengarahkan terjadinya peningkatan FS yang lebih cepat daripada laki-laki., ${ }^{2,-11}$

Perubahan fisiologis yang dihubungkan dengan FS merupakan hal yang kompleks. Kemungkinan terdapat interaksi antara sistem tertentu yang meningkatkan risiko FS, seperti inflamasi dan disregulasi endokrin (Gambar 2). Nutrisi yang inadekuat, bertambahnya usia, dan perubahan fisiologis yang terjadi dengan bertambahnya usia dapat mengarah pada terjadinya sarkopenia yang meningkatan risiko FS; terdapat bukti yag menunjukkan bahwa hal tersebut masih dapat dimodifikasi. Fiatarone et al. menunjukkan bahwa latihan penguatan dapat meningkatkan kekuatan ekstremitas bawah, kecepatan berjalan, dan kekuatan menaiki tangga pada lansia

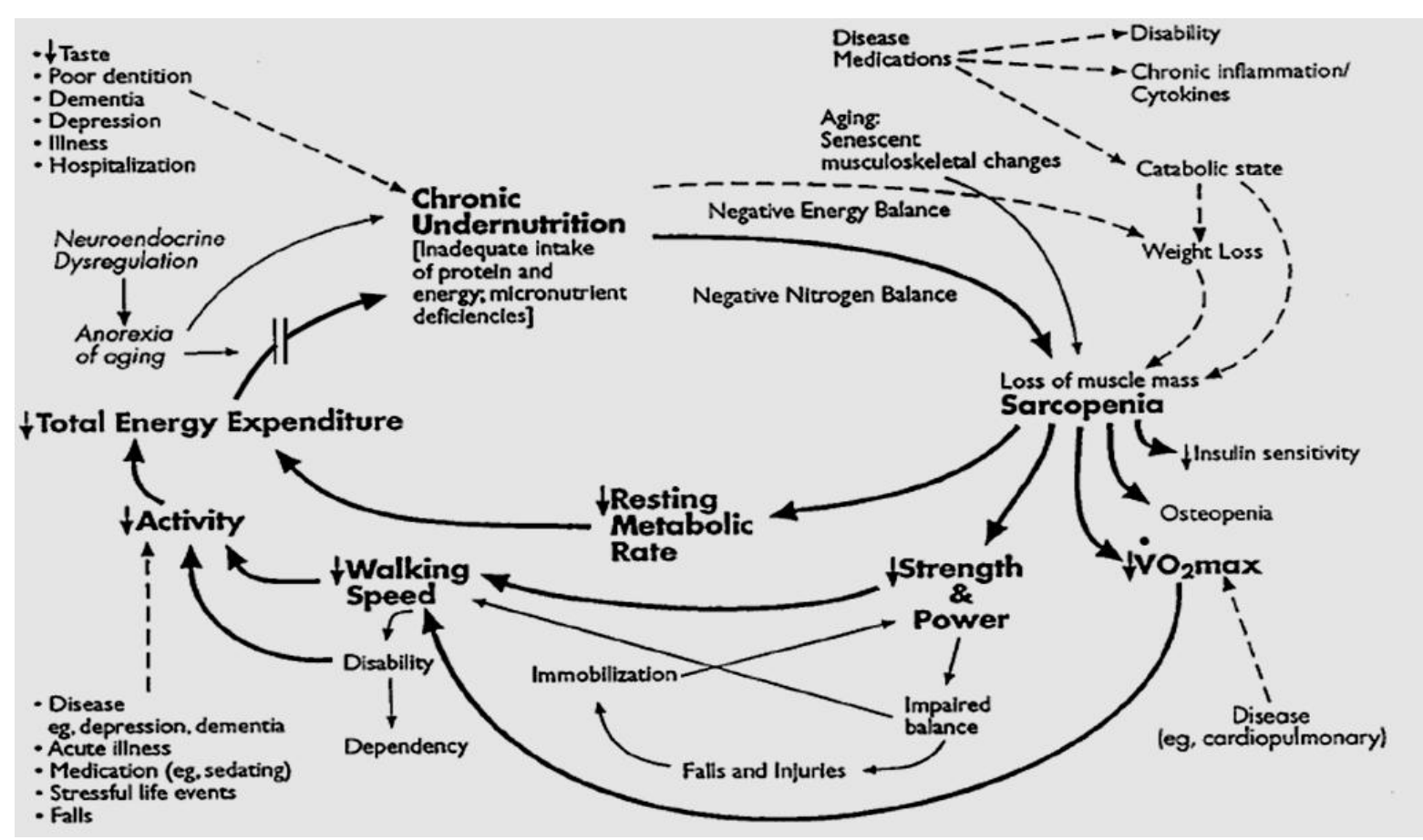

Gambar 1. Siklus frailty syndrome. Sumber: Fried et al., 2003. ${ }^{11}$ 


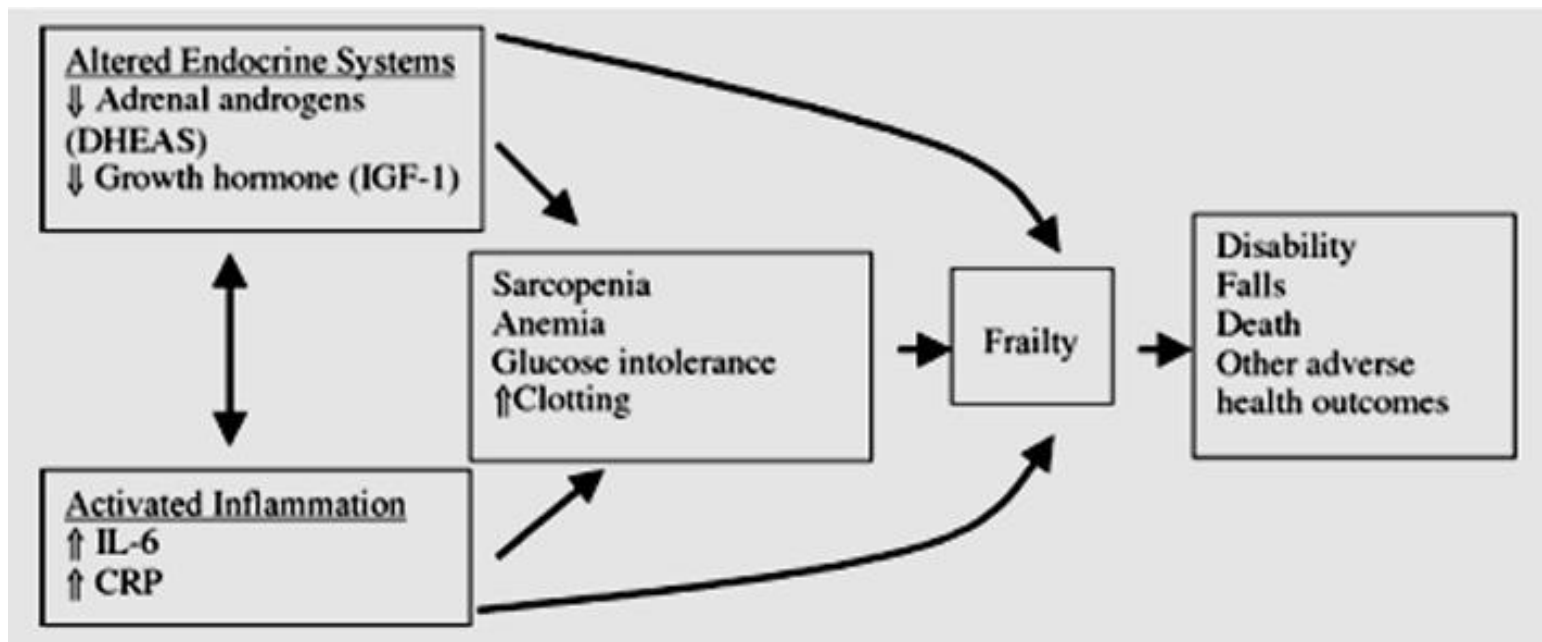

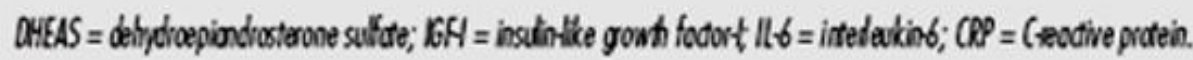

Gambar 2. Patofisiologi dari frailty syndrome. Sumber: Espinoza dan Fried. ${ }^{14}$

dengan FS yang tinggal di fasilitas perawatan. Latihan penguatan juga memperbaiki mobilitas dan aktivitas spontan sehingga dipikirkan bahwa peningkatan kekuatan otot mungkin dapat memutuskan siklus FS dengan cara menstimulasi peningkatan aktivitas. ${ }^{8-11}$

Lipsitz menunjukkan bahwa perubahan sistem tubuh mungkin mendasari kerentanan pada usia lanjut. Perubahan pada tingkat molekuler juga dapat memberikan kontribusi terhadap FS. Secara teoritis, Bortz telah mengusulkan teori physics of frailty yaitu berupa kehilangan kemampuan fungsional di tingkat selular dengan berkurangnya termodinamik serta hilangnya cadangan energi selular yang berakhir pada penurunan fungsi fisik. Fungsi fisiologik yang mengalami penurunan tersebut dapat mengakibatkan FS yang bermanifestasi sebagai berkurangnya kemampuan untuk mempertahankan homeostasis dalam menghadapi stresor, antara lain infeksi akut. ${ }^{3,14-16}$

\section{MASALAH DALAM FRAILTY SYNDROME}

Terdapat beberapa penyakit dan masalah medis yang berperan penting dalam menyebabkan FS, yaitu: anoreksia, sarkopenia, imobilisasi, aterosklerosis, gangguan keseimbangan, depresi, dan gangguan kognitif. $2,5,17-19$

Keadaan anoreksia sangat sering terjadi pada orang tua yang merupakan bagian dari proses penuaan. Masalah ini diperberat oleh beberapa penyakit tertentu dan menyebabkan keadaan malnutrisi kronis yang berakibat kelelahan, kelemahan, kaheksia (general wasting away), dan defisiensi mikronutrien (vitamin dan mineral). Masalah hormonal seperti defisiensi testoteron dapat memperburuk keadaan anoreksia.

Sarkopenia didefinisikan sebagai berkurangnya otot dalam jumlah besar yang berhubungan dengan proses penuaan. Hal ini dapat dipercepat oleh beberapa faktor seperti berkurangnya aktivitas fisik serta defisiensi hormon testoteron dan hormon pertumbuhan.

Imobilisasi dapat disebabkan oleh penyakit seperti artritis, yang menurunkan kemampuan untuk menggerakkan sendi atau oleh karena adanya nyeri. Penyakit dengan imobilisasi lama juga dapat menyebabkan kelelahan yang berakhir pada FS jika tidak segera ditangani.

Aterosklerosis yang mengakibatkan penyempitan dan penyumbatan arteri dapat meyebabkan FS karena berkurangnya oksigen $\left(\mathrm{VO}_{2}\right)$ yang mencapai jaringan dan organ. Penyumbatan arteri tersebut juga dapat menyebabkan stroke, yang mengarah 
pada terjadinya gangguan kognitif. Penyakit vaskuler pada daerah kaki akibat aterosklerosis akan mengakibatkan berkurangnya nutrisi otot, memperlambat kecepatan berjalan, dan terjadi sarkopenia.

Gangguan keseimbangan dapat dialami oleh setiap orang. Penurunan keseimbangan dapat memicu suatu lingkaran setan dimana keadaan terjatuh akan menimbulkan rasa takut, yang mengarah pada berkurangnya mobilitas dan memperburuk suatu FS. Untuk mengatasi gangguan kesimbangan ini dapat diberikan latihan keseimbangan, salah satunya yang sangat umum dipergunakan ialah Tai Chi.

Depresi dapat diakibatkan oleh berkurangnya mobilitas dan rasa kelelahan yang terus menerus. Depresi juga dapat memperlambat proses berpikir. Penyandang depresi lebih cenderung mengalami penyakit berat lainnya seperti infark miokard dengan pemulihan yang lebih lambat. Depresi juga menjadi penyebab utama dari anoreksia dan penurunan berat badan pada lansia.

Gangguan kognitif dapat mengarah pada kemunduran dalam proses mental seseorang dan kecepatan bereaksi, yang mengakibatkan bertambahnya frekuensi terjatuh.

\section{KRITERIA DAN TAHAPAN FRAILTY SYNDROME}

Fried telah memvalidasi sebuah gambaran yang lebih spesifik dari FS yang dijelaskan sebelumnya. Diagnosis FS ditegakkan berdasarkan tiga atau lebih dari lima kriteria yaitu kelemahan, berkurangnya kecepatan jalan, keluhan cepat lelah, menurunnya aktivitas, dan berkurangnya berat badan (Tabel 1).,

Menurut definisi Fried tersebut, FS bukan merupakan suatu penyakit tetapi suatu keadaan antara fungsional dan nonfungsional, serta antara sehat dan sakit. Terdapat dua fase dari FS, yaitu tahap awal dan tahap akhir. Tahap awal disebut juga sebagai pre-frailty $(<3$ tanda karakteristik FS). Seseorang dengan pre-frailty lebih mungkin untuk berkembang menjadi FS; mereka lebih mungkin untuk terjatuh, masuk rumah sakit, atau meninggal, tetapi resikonya masih lebih kecil daripada lansia dengan FS. Tahap akhir dari FS ialah endstage yang dikenal dengan istilah failure to thrive. ${ }^{4,17}$ Tahap ini digambarkan sebagai hilangnya berat badan, wasting, dependensi, dan mungkin termasuk gangguan kognitif yang tidak dapat diterangkan. ${ }^{1719}$

Tabel 1. Kriteria klinis frailty syndrome Fried $^{2}$

\begin{tabular}{|c|c|}
\hline Weakness & $\begin{array}{l}\text { Menggunakan dinamometer. } \\
\text { Laki-laki dikatakan positif } \\
\text { bila handgrip <30 kg, } \\
\text { perempuan }<18 \mathrm{~kg}\end{array}$ \\
\hline $\begin{array}{l}\text { Slow walking } \\
\text { speed }\end{array}$ & $\begin{array}{l}\text { Waktu tempuh } 4 \text { meter lebih } \\
\text { dari } 6 \text { detik dikatakan positif }\end{array}$ \\
\hline $\begin{array}{l}\text { Self-reported } \\
\text { exhaustion }\end{array}$ & $\begin{array}{l}0=\text { jarang; } 1=\text { kadang; }(1-2 \\
\text { hari }) ; 2=\text { sedang (3-4 hari); } \\
3=\text { sepanjang waktu. Nilai } \\
\text { positif yaitu } 2 \text { atau } 3\end{array}$ \\
\hline $\begin{array}{l}\text { Low level of } \\
\text { physical } \\
\text { activity }\end{array}$ & $\begin{array}{l}3 \text { bulan tanpa weight bearing } \\
\text { activity atau menghabiskan } \\
\text { waktu >4 jam duduk atau } \\
\text { melakukan jalan pendek }<1 \\
\text { kali perbulan }\end{array}$ \\
\hline $\begin{array}{l}\text { Unintentional } \\
\text { weight loss }\end{array}$ & $\begin{array}{l}>4,5 \mathrm{~kg} \text { dalam tahun terakhir } \\
\text { atau } 5 \% \text { dari berat badan }\end{array}$ \\
\hline
\end{tabular}

\section{FRAILTY SYNDROME DAN DISABILITAS}

Keadaan FS dan disabilitas saling tumpang tindih tetapi merupakan konsep yang terpisah. Disabilitas menunjukkan kesulitan atau ketergantungan dalam melakukan AKS. Frailty syndrome menunjukkan instabilitas atau risiko dari berkurangnya atau bertambah kurangnya suatu kemampuan fungsional. Disabilitas mungkin timbul dari satu keadaan katastrofik seperti stroke atau amputasi traumatik pada seseorang yang sehat dan kuat. Setelah pemulihan yang minor terjadi fluktuasi fungsional dari hari ke hari, sebagai contoh: pada keadaan artritis yang akan memburuk dalam cuaca dingin; atau seseorang dengan stroke akan menjadi lebih spastis dalam keadaan kesakitan. 2,7,9

Banyak individu yang mengalami FS 
juga mengalami disabilitas. Dalam penelitian Fried, sebanyak $72,8 \%$ lansia dengan FS tidak mengalami disabilitas dan $72 \%$ lansia dengan disabilitas tidak mengalami FS. Penelitian oleh Cardiovascular Health Study (CHS) menunjukkan hanya $27 \%$ individu yang mengalami disabilitas dalam melakukan AKS yang dikarakteristik sebagai FS. Frailty syndrome merupakan suatu prekusor fisiologik terhadap disabilitas, sehingga kemungkinan bahwa disabilitas sendiri yang menyebabkan berkurangnya aktivitas fisik, yang dapat mengarah pada terjadinya FS. ${ }^{5-10}$

Untuk menilai status fungsional lansia dengan cepat dapat dipergunakan skala FS yang didasarkan pada skala status geriatrik, yang dapat membantu mengidentifikasi apakah pasien membutuhkan intervensi khusus dalam suatu lembaga perawatan, dan untuk menilai persentase untuk bertahan hidup. $^{20}$

Frailty syndrome merupakan prediktor yang dapat dipercaya dari penurunan kesehatan secara umum, kejadian terjatuh, berkurangnya mobilitas, disabilitas, hospitalisasi, dan kematian. Frailty syndrome juga berhubungan erat dengan penyakit kardiovaskuler, rendahnya pendidikan, dan kemiskinan. ${ }^{2,7}$

\section{PENCEGAHAN FRAILTY SYNDROME}

Sebagian aspek FS dihubungkan dengan usia dan bersifat ireversibel. Frailty syndrome harus ditangani sebagai suatu tahap penting dalam perkembangan disabilitas dan penyakit yang serius. Keadaan tersebut harus dideteksi secara dini dan diberikan terapi yang tepat, sehingga dapat meningkatkan kualitas hidup para lansia. ${ }^{12,21}$

Beberapa tahapan yang penting untuk mencegah atau menunda terjadinya FS ialah: mempertahankan asupan makanan, latihan ketahanan, pencegahan aterosklerosis, menghindari isolasi, mengatasi nyeri, latihan Tai Chi, dan pengecekan kejadian testosteron secara teratur. ${ }^{21}$

\section{PENANGANAN FRAILTY SYNDROME}

Menentukan intervensi yang tepat merupakan langkah kritis lanjut dalam menurunkan efek FS pada lansia. Penanganan terbaik terhadap FS sangat bervariasi karena penyebabnya yang berbeda pada masing-masing individu. Langkah pertama ialah memberikan penanganan yang tepat terhadap penyakit atau masalah medis yang mendasarinya. ${ }^{22}$

Kerentanan fungsi dan faali pada individu dengan FS harus digunakan untuk memandu kita dalam merawat mereka. Umumnya individu dengan FS memiliki banyak masalah medis, dan banyak diantaranya tidak khas. Selain itu, berbagai keadaan sosial, psikologis, dan masalah fungsional semakin memengaruhi status kesehatan dari seorang penyandang FS yang harus selalu diikutsertakan dalam rencana perawatan yang komprehensif. ${ }^{1,2,15}$

Intervensi yang dapat diberikan yaitu obat-obatan, nutrisi, hormon, dan rehabilitasi berupa latihan fisik. Latihan fisik banyak memberi keuntungan, diantaranya meningkatkan mobilitas dalam AKS, perbaikan pola berjalan, serta berkurangnya resiko cedera dan jatuh.

Sejalan dengan proses penuaan, terjadi penurunan massa otot (pada usia 80 tahun massa otot berkurang hingga setengahnya) dan kekuatan otot. Beberapa penelitian menunjukkan manfaat latihan fisik pada lansia yang sehat, bahkan pada keadaan FS yang parah. Manfaat latihan fisik berupa peningkatan mobilitas, perbaikan performa dalam melakukan AKS, memperbaiki cara berjalan, mengurangi risiko terjatuh, meningkatkan densitas mineral tulang, dan memperbaiki kualitas hidup secara umum. $^{22,23}$

\section{LATIHAN FISIK}

Pada lansia terjadi penurunan massa otot dan kekuatannya, laju denyut jantung maksimal, toleransi latihan, kapasitas aerobik, serta terjadi peningkatan lemak tubuh. Bukti-bukti yang ada menunjukkan bahwa latihan dapat mencegah atau 
memperlambat terjadinya gangguan fungsional, bahkan latihan yang teratur dapat memperbaiki morbiditas dan mortalitas yang diakibatkan oleh penyakit kardiovaskuler. Hasil penelitian Edward dan Larson menyatakan bahwa: ${ }^{23}$

1. Latihan fisik dengan intensitas sedang dapat memberikan keuntungan bagi lansia melalui berbagai hal, antara lain status vaskuler, risiko fraktur, kemampuan fungsional, dan keadaan mental.

2. Latihan fisik harus disesuaikan secara individual, yaitu sesuai dengan tujuan pada individu tersebut. Jenis dan intensitas latihan perlu dipertimbangkan, antara lain latihan aerobik, penguatan, fleksibilitas, dan keadaan yang perlu diperhatikan saat latihan.

3. Latihan menahan beban (weight bearing exercise) yang intensif, misalnya berjalan, yang paling aman, murah, dan mudah, serta sangat bermanfaat bagi sebagian besar lansia.

4. Lansia yang sedenter harus dirangsang untuk melakukan latihan secara tetap. Whitehead menyatakan bahwa sebagian besar penelitian menunjukkan bahwa sedikit sekali perubahan pada kebugaran fisik yang terjadi bila latihan dilakukan kurang dari 3 kali per minggu, akan tetapi tidak terdapat penambahan keuntungan yang berarti bila latihan dilakukan lebih dari 5 kali per minggu.

Penelitian Nakagawa menunjukkan perbaikan yang bermakna dalam keseimbangan, kemampuan berjalan, serta perilaku sosial dan psikologis (kualitas hidup) dengan memberikan pasien FS suatu program latihan sederhana dan mudah untuk dilakukan, serta dapat dilakukan dalam lingkungan rumahnya. Latihan penguatan otot tersebut dilakukan dalam hitungan satu set yang terdiri dari 8-10 repetisi dan latihan peregangan selama 1020 detik. Intensitas masing-masing set tergantung dari kekuatan otot masingmasing subyek, dimulai dari 12-13 RPE (Rating of perceived exertion) yang termasuk aktivitas yang sedikit berat. Waktu latihan keseluruhan yang dianjurkan sekitar 20 menit, dengan mempertimbangkan terjadinya kelelahan. Latihan ini dianjurkan untuk dilakukan 1-2 hari dalam seminggu. ${ }^{22,25}$

Program latihan fisik bagi lansia mempunyai jenis dan intensitas latihan yang berbeda dengan usia muda, apalagi bagi seorang atlit. Seiring dengan peningkatan kebugaran, latihan dapat ditingkatkan secara bertahap. Latihan dengan intensitas ringan secara umum didefinisikan sebagai $<50 \%$ kapasitas aerobik maksimal; sedang 50-70\% kapasitas aerobik maksimal; dan berat $>70 \%$ kapasitas aerobik maksimal. Latihan fisik juga dapat diukur dan diatur dalam bentuk ekuivalen metabolik (METS) yang merupakan konsumsi oksigen saat istirahat atau 3,5 $\mathrm{ml} / \mathrm{O}_{2} / \mathrm{kgBB} /$ menit. Rentang latihan yang aman bagi lansia dengan tes stres yang normal ialah 4-7 METS. ${ }^{23-25}$

Walaupun peresepan latihan yang sempurna untuk FS tidak diketahui, penelitian menunjukkan bahwa latihan dengan tahanan memberikan manfaat walaupun hanya dilakukan 2 kali seminggu. Latihan fisik yang dilakukan selama 3060 menit 3 kali seminggu selama 3-6 bulan, menunjukkan perbaikan tanda-tanda FS. Sebelum melakukan program latihan fisik perlu dilakukan berbagai evaluasi keadaan fisik dan kesehatan lansia. Selain untuk menjaga kemungkinan terjadinya komplikasi atau cedera akibat latihan fisik, hal tersebut juga untuk menilai berbagai jenis latihan yang sesuai bagi individu lansia tersebut. $^{22-24}$

\section{SIMPULAN}

Frailty Syndrome (FS) adalah suatu sindroma geriatrik dengan karakteristik berkurangnya kemampuan fungsional dan gangguan fungsi adaptasi yang diakibatkan oleh merosotnya berbagai sistem dalam tubuh, serta meningkatnya kerentanan terhadap berbagai macam tekanan, yang akan menurunkan performa fungsional seseorang dan berakibat buruk terhadap 
kesehatan. Memperbaiki faktor-faktor risiko dan perubahan hormon dapat membantu mencegah seseorang yang rentan supaya tidak masuk ke dalam keadaan FS. Rehabilitasi geriatrik akan menjadi bagian yang penting dalam fasilitas pelayanan kesehatan untuk populasi lansia dengan FS dalam tahun-tahun mendatang.

\section{DAFTAR PUSTAKA}

1. Mangien KK. The frail and institutionalized elder. In: Guccione AA, editor. Geriatric Physical Therapy (Second Edition). Missouri: Mosby, 2000; p.445-54.

2. Cherniack EP, Florez HJ, Troen BR. Emerging therapies to treat frailty syndrome in the elderly. Alternative Medicine Review. 2007;12(3):246-58.

3. Fried LP, Tangen CM, Walston J, Newman AB, Hirsch C, Gottdiener J, et al. Frailty in older adults: evidence for a phenotype. J Gerontol Med Sci. 2001;56A:M146-M156.

4. Buchner DM, Wagner EH. Preventing frail health. ClinGeriatr Med. 1992;8(1):117.

5. Peddi R, morley J. The physiology of aging. In: Meldon SW, Ma OJ, Woolard R, editors. Geriatric Emergency Medicine. New York: McGraw-Hill, 2004: p.4-11.

6. Fried LP, Walston J. Frailty and failure to thrive. In: Hazzard WR, Blass JP, Ettinger WH Jr, Halter JB, Ouslander J, editors. Principles of Geriatric Medicine and Gerontology (Fourth Edition). New York: McGraw-Hill, 1998; p.1387-402.

7. Chin AP, Dekker JM, Feskens EJM, Schouten EG, Kromhout D. How to select a frail elderly population? A comparison of three working definitions. J Clin Epidemiol. 1999;52(11):1015-21.

8. Dayhoff NE, Suhrheinrich J, Wigglesworth J, Topp R, Moore S. Balance and muscle strength as predictors of frailty among older adults. J Gerontol Nurs. 1998;24(7):18-27.

9. Walston J, Fried LP. Frailty and the older man. Med ClinNorth Am. 1999;83(5):1173-94.
10. Verdery RB. Failure to thrive in the elderly [Review]. ClinGeriatr Med. 1995;11(4):653-9.

11. Fried LP, Jonathan D, Jeremy W. Frailty. In: Christine KC, Rosanne ML, Harvey JC, Eric BL, Diane EM, editors. Geriatric Medicine - an evidence based approach (Fourth Edition). New York: Springer-Verlag, 2003; p. 1067-76.

12. Corti MC, Guralnik JM, Salive ME, Sorkin JD. Serum albumin level and physical disability as predictors of mortality in older persons. JAMA. 1994;272(13):1036-42.

13. Berkman B, Foster LWS, Campion E. Failure to thrive: paradigm for the frail elder. Gerontologist. 1989;29(5):654-9.

14. Espinoza SE, Fried LP. Risk factors for frailty in the older adult. Geriatric syndrome. Clinical Geriatric. 2007;15(6):37-44.

15. Lipsitz LA, Goldberger AL. Loss of "complexity" and aging. Potential applications of fractals and chaos theory to senescence. JAMA. 1992;267(13):1806-9.

16. Williamson JD, Fried LP. Characterization of older adults who attribute functional decrements to "old age". Journal of the American Geriatrics Society. 1996;44(12):1429-34.

17. Brown M, Sinacore DR, Ehsani AA, Binder EF, HolloszyJO, Kohrt WM. Low-intensity exercise as a modifier of physical frailty in older adults. Arch Phys Med Rehabil. 2000;81(7):960-5.

18. Fiatarone MA, O'Neil EF, Ryan ND, Clements KM, Solares GR, Nelson ME, et al. Exercise training and nutritional supplementation for physical frailty in very elderly people. $\mathrm{N}$ Engl $\mathrm{J}$ Med. 1994;330(25):1769-75.

19. Evans WJ. Effects of exercise on body composition and functional capacity of the elderly [Review]. J Gerontol ABiol Sci Med Sci. 1995;50(spec no):147-50.

20. Roockwood K, Stadnyk K, MacKnight C, McDowell I, Hebert R, Hogan DB. A brief clinical instrument to classify frailty in elderly people. Lancet. 1999;353:205-6.

21. Espinoza SE, Walston JD. Frailty in older adults: Insight and interventions. Cleveland Clinic Journal of Medicine. 2005;72:1105-11. 
22. Martono HH, Darmojo RB. Olah raga dan kebugaran pada usia lanjut. In: Darmojo $\mathrm{RB}$, Martono HH, editors. Buku Ajar Geriatrik (Ilmu Kesehatan Usia Lanjut). Jakarta: Balai Penerbit Fakultas Kedokteran Universitas Indonesia, 2006; p. 93-101.

23. Soegiarto B, Suyono YJ, Anggraini D. In: Soegiarto B, Suyono YJ, Anggraini D, editors. ACSM Panduan Uji Latihan
Jasmani dan Peresepannya (Edisi Kelima). Jakarta: Penerbit Buku Kedokteran EGC, 2004; p. 196-201.

24. Nakagawa $K$, Inomata $N$, Konno $Y$, Nakazawa R, Hagiwara K, Sakamoto M. The characteristic of a simple exercise program under the instruction of physiotherapists - for general elderly people and frail elderly people. J.Phys.Ther.Sci. 2008;20:197-203. 